\title{
Prevalence and Determinants for Hypertension among Rural Women of Reproductive Age in Indonesia
}

\author{
Yessi Octaria ${ }^{1,2 *}$, Ali Khomsan ${ }^{2}$, Ikeu Tanziha ${ }^{2}$, Dadang Sukandar ${ }^{2}$ \\ ${ }^{1}$ Center for Public Health Innovation, Faculty Medicine Udayana University, Bali 80361, Indonesia \\ ${ }^{2}$ Department of Community Nutrition, Faculty of Human Ecology, IPB University, \\ Bogor 16680, Indonesia
}

\begin{abstract}
This study aimed to investigate the prevalence and determinants of hypertension in rural women of reproductive age. The cross-sectional study was conducted in Cianjur district on August 2019. It involved 193 married rural women aged 20-49 years old. Independent variables investigated were socio-economic characteristics, anthropometry, fat distribution and nutrient intake. The prevalence of hypertension in the study population using the new American Guideline (ACC/AHA) was 58\% in contrast to $23.8 \%$ using the European (ESC/ESH) cut offs. Socioeconomic characteristics and nutrient intake showed no significant association with hypertension ( $p>0.05)$ while, Body Mass Index (BMI) $(\mathrm{p}>0.012)$, Visceral Fat (VF) $(\mathrm{p}>0.013)$ and Waist Circumference (WC) $(\mathrm{p}>0.010)$ were significantly associated with hypertension. Hence, result of binary logistic regression showed waist circumference is the strongest factor to determine hypertension in our study ( $\mathrm{OR}=2.2 ; 95 \%$ CI: $1.20-4.01)$. Overall, the use of the American guideline increases the sensitivity of hypertension screening. The use of simple anthropometry measurement of WC combined with BMI can be applied for risk screening of hypertension in the primary health care setting including in the integrated community health post to improve preventive measure. Due to several limitations in the current study, future study should consider larger sample size and addresses history of hormonal contraceptive use as well as physical activity.
\end{abstract}

Keywords: hypertension, waist circumference, women

\section{INTRODUCTION}

The number of adults with hypertension has increased rapidly, where the low-income and middle-income countries are the greatest contributors (NCD-RisC 2017) Globally, high Systolic Blood Pressure (SBP) is the highest leading cause of DALY lost in female population, it accounted for 89,9 million DALYs; 80,9 million to 98,2 million in 1990 to 2016 (GBD 2017). At national level, the prevalence of high blood pressure among women aged $\geq 18$ years old in Indonesia was $36.85 \%$ which is higher compared to the male population. Moreover the prevalence among farmers and those living in West Java were also high (MoH RI 2019a).

Older women as they aged and their estrogenic level is decreasing, are more prone to hypertension (Wenger et al. 2018). However, Hypertension is a chronic condition where the pathophysiology may rises long before the actual increase of blood pressure. Thus, in order to improve preventative measure screening of blood pressure and its risk among younger age group is pivotal. In addition, despite the relatively lower prevalence of hypertension in women of reproductive age, hypertension in women within this age group has its own specific clinical implications and challenges such as when the women with hypertension become pregnant. Women with chronic hypertension showed higher risk of adverse pregnancy outcomes such as preterm delivery, foetal growth restrictions as well as perinatal death amongst other (Bramham et al. 2014).

In Indonesia, around $44 \%$ of all female within the reproductive age of $20-49$ years are living in rural area (BPS 2018). The rural and urban population are facing different risk factors, with the rural population often lack in health care access and utilization. In China, awareness and treatment control of hypertension were better in urban setting compared to the rural area, despite the similar prevalence ( $\mathrm{Li}$ et al. 2017).

"Corresponding Author: tel: +6287761702726, email: yessicrosita@gmail.com 
In Indonesia, the welfare statistics also mirror the same insight, where only less than half of the rural women seek health care when they are sick (BPS 2018). Therefore, a study focusing on rural women of reproductive age will provide information on how to reduce the morbidity and mortality related to hypertension within this specific population.

Due to the importance of hypertension in the community, experts in this field issued guidelines on its management periodically. The latest European guidelines retain the previous definition of hypertension (BP $>140 / 90 \mathrm{mmHg}$ ) (Williams et al. 2018). Whereas the new American guidelines lowered the threshold to define hypertension to $<130 / 80 \mathrm{mmHg}$ (Goel et al. 2019) The lower cut off is important for two epidemiological reasons. The first is that high blood pressure is still the main risk factor for mortality and morbidity. Secondly, several metaanalyses indicate that the risk of coronary events and stroke among subjects with SBP between 130 and 139 is $1.5-2$ times higher compared to those who have SBP of below 120 (Sierra 2019).

The same argument is also used by experts in India to advocate adoption the American College of Cardiology (ACC)/American HeartAssociation (AHA) guidelines (Chopra \& Ram 2019). On a larger context of Asian population with stroke as the dominant complication of hypertension not cardiac events, the use of relatively low diagnostic thresholds and therapeutic targets $(130 / 80 \mathrm{mmHg})$, as suggested by the ACC/AHA Guidelines considered more acceptable (Angeli et al. 2019). Thus, acknowledging the need for aggressive BP goals and lower diagnostic threshold bot at clinical setting and screening purposes will provide enormous public health benefit for Asian population.

Indonesian women and farmers are among the most affected based on the recent national health survey data. However, to our knowledge previous study done regarding hypertension in rural adult population in Indonesia was focused on older age group, not specific in women and utilizing higher cut off value for diagnosis (Diana et al. 2018). Hence, due to paucity of research on hypertension among rural women of reproductive age utilizing the recent ACC/AHA guidelines, the study aimed to investigate the prevalence and determinants of hypertension in the target population.

\section{METHODS}

\section{Design, location, and time}

The cross-sectional study was conducted in Sukabungah and Campaka Mulya Villages, Cianjur district-West Java, Indonesia on August 2019.

\section{Sampling}

The minimum sample size was calculated using the Lameshow equation (Pourhoseingholi et al. 2013) with $95 \%$ CI, $10 \%$ precision and previous known prevalence for hypertension of $36.85 \%$ among Indonesian female population (MoH RI 2019a). The study involved 193 married rural women aged 20-49 years old, the exclusion criteria were pregnancy and any physical disability that prevent accurate measurement of anthropometry, body fat distribution or blood pressure. The ethical clearance for the study was issued by the Ethical Committee of IPB University in Bogor (Number 210/IT3.KEPMSM-IPB/ SK/2019).

\section{Data collection}

Blood pressure measurement. Blood pressure was measured in health facility in the morning (08.00-11.00 a.m.) with around 15 minute rest after the respondents were arriving at the facility. Measurement was done using an automatic blood pressure monitor on the left arm with a validated upper-arm-cuff device (OMRON-HEM7130). Respondent was in relaxed sitting position, legs not crossed, not talking, arm rested on the table level to the heart. Average of three measurements was taken, the three measurements were taken sequentially with more than one minute apart. On an important note, such measurement alone is not appropriate for the diagnosis of hypertension in untreated subjects, however it does have a role in screening for hypertension (Stergiou et al. 2018). Shortly following the blood pressure measurement, respondents were asked "Have you ever diagnosed with high blood pressure (hypertension)?" Those responding affirmatively, were then asked if they had taken any medication for high blood pressure in the last one month.

Socio-economic characteristics. In addition to age (date of birth), data regarding education level, income level, and occupation status were also obtained via interview using 
a structured questionnaire. The interview for individual characteristics were done at home before the physical examination was performed parallel to the first 24 hours food recall.

Nutrient intake. The nutrients intake data was obtained from $2 \times 24$ hours food recall, first taken at home during a workday and second at the health facility during weekend. The food recall process was assisted with the national food photograph book to increase precision. Nutrient intake value were obtained from NutriSurvey ${ }^{\circledR}$ for Windows 2007 app, incorporating the nutrient from the Indonesian food data base. Nutrient intake obtained were nutrients related to Dietary Approaches to Stop Hypertension (DASH) diet. (Kim \& Andrade 2016).

\section{Anthropometry and fat distribution measurements. The anthropometry} measurements were taken after the blood pressure measurement. Height, waist circumference, body weight, Body Mass Index (BMI), visceral fat and total body fat composition were performed. Body height was measured with a stadiometer with a capacity of $200 \mathrm{~cm}$ and an accuracy of $0.1 \mathrm{~cm}$. The waist circumference was measured with a measuring tape with a capacity of $150 \mathrm{~cm}$ and an accuracy of $0.1 \mathrm{~cm}$. The body weight, BMI and fat composition were measured with a four electrodes (two hands and two feet) Bioelectrical Impedance Analysis (BIA) monitor $\left(\mathrm{OMRON}^{\circledR}\right.$ Karada Scan Body Composition Monitor HBF358-BW) in light clothing without shoes or socks on.

\section{Data analysis}

Hypertension was defined as mean Systolic Blood Pressure (SBP) $\geq 130 \mathrm{mmgHg}$ or Diastolic Blood Pressure (DBP) $\leq 80 \mathrm{mmHg}$, following the new ACC/AHA guidelines (Sierra 2019).

Short stature was defined as height $\leq 152$ cm (Ferreira et al. 2009). Respondents' age, education and income level were classified into three groups. For age the groups were 20-29 years, 30-39 years and 40-49 years. While for education the classification were elementary school or lower, Junior high school and senior high school or higher. The category for household income level were household income of under one million, one to two millions and above two millions rupiah per month, where 1,8 million rupiah per month is the minimum regional wage in the West Java province. Mothers were categorized into working mother and home maker.

The BMI category was based on the Asian cut off for overweight and obesity which is $\geq 23$ $\mathrm{kg} / \mathrm{m}^{2}$ for elevated risk of non-communicable disease (WHO 2004). The visceral fat cut off measured by BIA to define metabolic syndrome in our study was 9\% (Ozhan et al. 2012), as for the waist circumference we refer to the Asian female population of above $80 \mathrm{~cm}$ for increased risk of metabolic syndrome (WHO 2008). Regarding nutrient intake, the respondents' nutrients intake for each nutrient was categorized in two groups of lower risk and high risk. The cut off value for increased or higher risk of hypertension from each nutrient was based on the DASH diet cut off namely for saturated fat $\leq 6 \%$ of energy, total fat $\leq 27 \%$ of energy, protein $\geq 18 \%$ of energy, fibre $\geq 14.8 \mathrm{~g} / 1,000 \mathrm{kcal}$ and sodium $\leq 1,143 \mathrm{mg} / 1,000$ kcal (Mellen et al. 2008).

All collected data in this report are first presented in a descriptive statistics. Further analysis of the associations between variables with the occurrence of hypertension as dependent variable were done using the Chi-square test $(p<0.05)$. Binary logistic regression using the backward Wald method was performed to analyse the factors that determine hypertension involving all significant factors resulted from the Chi square test.

\section{RESULTS AND DISCUSSION}

\section{Prevalence of hypertension}

The prevalence of hypertension screened using the ACC/AHA guidelines in our study population was $58 \%$ or more than double the prevalence if measured using the $\mathrm{ESC} / \mathrm{ESH}$ guideline which was only $23.8 \%$. The large majority of the respondents $(96.4 \%)$ have never diagnosed for hypertension. Among those who have ever been diagnosed with hypertension, none were currently taking any blood pressure medication during the past month. The average SBP in our study was $122.2 \mathrm{mmHg}$ (SD $15.5 \mathrm{mmHg}$ ) while for the DBP was $81.0 \mathrm{mmHg}$ (SD $8.9 \mathrm{mmHg}$ ), this diastolic blood pressure is above the ACC/ AHA cut off for DBP (Sierra 2019).

\section{Socio-economic characteristics}

The average age was 31.15 (SD 6.84) years. Their education level were mostly low with 
$66.3 \%$ of them had an elementary school level education or lower and only $4.7 \%$ had a senior high school level education or higher. As for income level, more than half of our respondents were from the lower household's income group. The Chi square test did not show any significant association between soci economic characteristics with hypertension as shown in Table 1. However it is important to highlight that although it was not statistically significant, hypertension prevalence was observed the highest in oldest age group where $76.2 \%$ of women in the age of 40 49 had high blood pressure. In the U.S, women aged 35-44 years had a three times higher risk for hypertension compared to women aged 2025 years old (Chen \& Chauhan 2019). On an important note for our study method, is that the main pathophysiology for risk of hypertension in older women is related to the exposure to the sex hormone. Meta-analysis had shown certain duration of hormonal contraception such as the oral contraceptive use increases the risk for clinical hypertension (Liu et al. 2017). Therefore, the limitation of this study was to not take any history of hormonal contraceptive, which should be considered in future research.

In addition to age, more than half of the women from the two households' income brackets of lower than 2 million rupiah were suffering from hypertension compared to around $40 \%$ in the highest income level. Studies have shown conflicting evidence on the associations of income and hypertension among women in the developing countries. Studies from South Africa and India showed that women with higher socio economic level had lower risk of hypertension (Cois \& Ehrlich 2014; Tyagi et al. 2015). But, in Mexico, increased socio-economic status positively correlated to the increase in SBP among low income women (Fernald \& Adler 2008). Therefore, more robust methodology is needed to define the associations between income and hypertension.

\section{Nutrient intake}

Overall, the average intake of energy, protein, fat, fibre and sodium of our respondents were lower than the national RDI for nonpregnant woman aged 19-29 and 30-49 years old (MoH RI 2019b). The average intake for macro nutrients and micronutrients of interest are as follow: energy intake was $1,347 \mathrm{kcal}$ (SD $458 \mathrm{kcal}$ ), Protein intake $40.6 \mathrm{~g}$ (SD $16.8 \mathrm{~g}$ ), total fat intake $46.5 \mathrm{~g}$ (SD $23 \mathrm{~g}$ ), fibre intake $5.8 \mathrm{~g}$ (SD $3 \mathrm{~g}$ ),

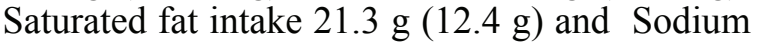
intake $629 \mathrm{mg}$ (SD $447 \mathrm{mg}$ )

The Chi square test showed no significant associations between nutrient-intake for protein, total fat, saturated fat, sodium and fibre according to the DASH nutrient cut off value presented in method (Mellen et al. 2008) with hypertension in our respondents (Table 2). Despite the non significant associations for protein and total fat intake, higher prevalence of hypertension were

Table 1. Chi square test for socio-economic characteristics

\begin{tabular}{|c|c|c|c|c|c|}
\hline \multirow{2}{*}{ Independent variables } & \multicolumn{2}{|c|}{ Normal blood pressure } & \multicolumn{2}{|c|}{ Hypertension } & \multirow{2}{*}{$\mathrm{p}$ value } \\
\hline & $\mathrm{n}$ & Observed \% & $\mathrm{n}$ & Observed \% & \\
\hline \multicolumn{6}{|l|}{ Age } \\
\hline $20-29$ & 37 & $42.5 \%$ & 50 & $57.5 \%$ & \multirow[t]{3}{*}{0.184} \\
\hline $30-39$ & 39 & $45.9 \%$ & 46 & $54.1 \%$ & \\
\hline $40-49$ & 5 & $23.8 \%$ & 16 & $76.2 \%$ & \\
\hline \multicolumn{6}{|l|}{ Education } \\
\hline Elementary school or lower & 54 & $42.2 \%$ & 74 & $57.8 \%$ & \multirow[t]{2}{*}{0.931} \\
\hline Junior high school or higher & 27 & $41.5 \%$ & 38 & $58.5 \%$ & \\
\hline \multicolumn{6}{|l|}{ Income } \\
\hline$<1$ million & 41 & $41.8 \%$ & 57 & $58.2 \%$ & \multirow[t]{3}{*}{0.176} \\
\hline 1-2 Million & 26 & $36.6 \%$ & 45 & $63.4 \%$ & \\
\hline$>2$ million & 14 & $58.3 \%$ & 10 & $41.7 \%$ & \\
\hline \multicolumn{6}{|l|}{ Occupation } \\
\hline Home maker & 20 & $48.8 \%$ & 21 & $51.2 \%$ & \multirow[t]{2}{*}{0.319} \\
\hline Working & 61 & $40.1 \%$ & 91 & $59.9 \%$ & \\
\hline
\end{tabular}

Significant ${ }^{*} \mathrm{p}<0.05$ 
found in respondents who consumed protein lower than $18 \%$ of the total energy and fat of higher than $27 \%$ of total energy intake. These findings are consistent to studies pointing out that protein is likely a protective factor for high blood pressure. (Elliott et al. 2006; Buendia et al. 2015) Recent study among 28,100 adult U.S women found that higher intake of Saturated Fatty Acids (SFAs), Mono Unsaturated Fatty Acids (MUFAs), and trans FAs was each associated with increased risk of hypertension among middle-aged and older women, whereas only association for trans Fatty Acids (FAs) remained statistically significant after adjustment for obesity-related factor (Wang et al. 2010).

We found no significant association between sodium intake and hypertension. Prolonged high sodium intake will cause increased sodium level in the cerebrospinal fluid, which activates the increasing sympathetic outflow and leading to hypertension. (Takahashi et al. 2011). The lack of association found within our study might related to the fact that the sodium intake of all our respondents was low.

In addition to protein, fibre intake is considered as a protective factor for hypertension. A Meta-analysis of Randomized Placebo Controlled Trials found that fibre supplementation reduced both systolic and diastolic BP (Streppel et al. 2005). While for the protective mechanism of fibre against hypertension several hypothesis were raised. The $\beta$-Glucan and other soluble fibre components have been proposed to have in particular hypo-cholesterolemic effects, but fibre can also improve glycaemia, insulin resistance, triglyceride levels and weight loss. These effects could probably lead to an improved cardiovascular condition thus resulted in better cardiac health and lower blood pressure (Aleixandre \& Miguel 2016). Sadly, in our respondents the average intake of fibre was very low of around $20 \%$ from the national RDI for non-pregnant women of reproductive age and all were below the DASH cut off value. Hence, an education on the adequate amount of intake with easy to understand message and visual cue is pressing to improve consumption of fibre as protective factors for hypertension among this population.

\section{Anthropometry and fat distribution}

The average BMI of our respondents was $25.87 \mathrm{~kg} / \mathrm{m}^{2}$ (SD $4.2 \mathrm{~kg} / \mathrm{m}^{2}$ ) this is above the Asian cut off for higher risk of chronic noncommunicable diseases of $23 \mathrm{~cm}$ (WHO 2004). The total body fat level was also above the normal $30 \%$ cut off the same goes for waist circumference in which the average was $85.61 \mathrm{~cm}(\mathrm{SD} 24.7 \mathrm{~cm})$

Table 2. Chi square test for nutrient intake

\begin{tabular}{|c|c|c|c|c|c|}
\hline \multirow{2}{*}{ Nutrient intake } & \multicolumn{2}{|c|}{ Normal blood pressure } & \multicolumn{2}{|c|}{ Hypertension } & \multirow{2}{*}{$\mathrm{p}$ value } \\
\hline & $\mathrm{n}$ & Observed $\%$ & $\mathrm{n}$ & Observed $\%$ & \\
\hline \multicolumn{6}{|l|}{ Protein intake } \\
\hline Equal to or higher than $18 \%$ of energy intake & 3 & $60.0 \%$ & 2 & $40.0 \%$ & 0.41 \\
\hline Lower than $18 \%$ of energy intake & 78 & $41.5 \%$ & 110 & $58.5 \%$ & \\
\hline \multicolumn{6}{|l|}{ Total fat intake } \\
\hline Equal to or lower than $27 \%$ of energy intake & 31 & $46.3 \%$ & 36 & $53.7 \%$ & 0.38 \\
\hline Higher than $27 \%$ of energy intake & 50 & $39.7 \%$ & 78 & $60.3 \%$ & \\
\hline \multicolumn{6}{|l|}{ Saturated fat } \\
\hline Equal to or lower than $6 \%$ of energy intake & 45 & $41.7 \%$ & 63 & $58.3 \%$ & 0.92 \\
\hline Higher than $6 \%$ of energy intake & 36 & $42.4 \%$ & 49 & $57.6 \%$ & \\
\hline \multicolumn{6}{|l|}{ Sodium } \\
\hline Lower than or equal to $1,143 \mathrm{mg} / 1,000 \mathrm{kcal}$ & 75 & $41.9 \%$ & 104 & $58.1 \%$ & 0.94 \\
\hline Higher than $1,143 \mathrm{mg} / 1,000 \mathrm{kcal}$ & 6 & $42.9 \%$ & 8 & $57.1 \%$ & \\
\hline Fibre & \multicolumn{5}{|c|}{$\begin{array}{l}\text { Analysis for fibre intake were unable to be performed since } \\
\text { the variable is a constant (all are below the } 30 \mathrm{~g} \text { cut off) }\end{array}$} \\
\hline
\end{tabular}

Significant * $\mathrm{p}<0.05$ 
or above the $80 \mathrm{~cm}$ cut off (WHO 2008). This anthropometry measurement were in contrast to the total energy intake as recorded from the 24 hours food recall, thus under reporting of intake might have caused the discrepancy. On the other hand, the average visceral fat of our respondents were $7.53 \%$ (SD $4.2 \%$ ) or lower than the $9 \%$ cut off applied in Egyptian population (Ozhan et al. 2012). The average height of our respondents was also low $(14.8 \mathrm{~cm}$; SD $4.7 \mathrm{~cm})$ or below the $152 \mathrm{~cm}$ cut off for short stature.

The Chi-square test result showed that Body Mass Index (BMI) ( $p>0.012)$, Visceral Fat $(p>0.013)$ and Waist Circumference $(p>0.010)$ were significantly associated with hypertension. While for total body fat and height, the prevalence were higher among respondents with higher total body fat $(61 \%)$ and shorter stature $(61.3 \%)$. The Chi square test results are presented in Table 3. These result are in line with many studies on determinants of hypertension where, higher BMI were positively associated with both prehypertension and hypertension in adult (Khanam et al. 2015; Kibria et al. 2019; Chen \& Chauhan 2019).

Associations between early growth and cardiovascular disease, first shown by Barker, have been found in many studies. Our result shows the prevalence of hypertension among shorter women (height $<152 \mathrm{~cm}$ ) was $61.3 \%$ compared to
$49 \%$ among taller women. A study of Brazilian women found that short stature, independent of confounding by race and environmental factors, was an important risk factor for hypertension among women. (Sichieri et al. 2000). More recent study consistently found that Brazilian women of short stature presented a higher prevalence of chronic degenerative diseases (Ferreira et al. 2009). This finding might be used in future studies to identify factors related to the pathogenesis of hypertension linked to developmental and nutrition problems such as stunting.

Metanalysis study showed that the use of BMI alone to diagnose obesity despite of its specificity, provides low sensitivity to identify adiposity or excess body fat (Okorodudu et al. 2010). The association of waist circumference and hemodynamic has been long studied. In Indonesia, a case control study in Surabaya showed that Waist Circumference (WC) as the strongest determinant for hypertension in clinical setting (Mafaza et al. 2016). Consistently, a cross sectional study in rural population of older adult in Indonesia also showed the same result, where respondents with a waist circumference of above the normal cut off had a four times greater chance for hypertension (Diana et al. 2018).

Binary logistic regression analysis on variables significantly associated with hypertension namely, BMI, waist circumference

Table 3. Chi square test for anthropometric assessment

\begin{tabular}{|c|c|c|c|c|c|}
\hline \multirow{2}{*}{ Variable } & \multicolumn{2}{|c|}{ Normal blood pressure } & \multicolumn{2}{|c|}{ Hypertension } & \multirow{2}{*}{$\mathrm{p}$ value } \\
\hline & $\mathrm{n}$ & Observed \% & $\mathrm{n}$ & Observed \% & \\
\hline \multicolumn{6}{|l|}{ Body mass index } \\
\hline$<23$ & 29 & $56.9 \%$ & 22 & $43.1 \%$ & \multirow{2}{*}{$0.012 *$} \\
\hline$\geq 23$ & 52 & $36.6 \%$ & 90 & $63.4 \%$ & \\
\hline \multicolumn{6}{|l|}{ Height } \\
\hline$\geq 152$ & 26 & $51.0 \%$ & 25 & $49.0 \%$ & \multirow[t]{2}{*}{0.128} \\
\hline$<152$ & 55 & $38.7 \%$ & 87 & $61.3 \%$ & \\
\hline \multicolumn{6}{|l|}{ Visceral fat } \\
\hline$<9$ & 61 & $48.4 \%$ & 65 & $51.6 \%$ & \multirow[t]{2}{*}{$0.013 *$} \\
\hline$\geq 9$ & 20 & $29.9 \%$ & 47 & $70.1 \%$ & \\
\hline \multicolumn{6}{|l|}{ Total body fat } \\
\hline$<30$ & 26 & $50.0 \%$ & 26 & $50.0 \%$ & \multirow[t]{2}{*}{0.170} \\
\hline$\geq 30$ & 55 & $39.0 \%$ & 86 & $61.0 \%$ & \\
\hline \multicolumn{6}{|c|}{ Waist circumference } \\
\hline$<80$ & 37 & $54.4 \%$ & 31 & $45.6 \%$ & \multirow[t]{2}{*}{$0.010^{*}$} \\
\hline$\geq 80$ & 44 & $35.2 \%$ & 81 & $64.8 \%$ & \\
\hline
\end{tabular}

Significant ${ }^{*} \mathrm{p}<0.05$ 
and visceral fat categories showed that waist circumference is the strongest determinant for hypertension in our study population (Table 4). Respondents with a waist circumference of $\geq 80$ $\mathrm{cm}$ had 2.2 times risk to suffer from hypertension $(\mathrm{OR}=2.2$; 95\% CI: $1.20-4.01)$.

The Chi-square and binary logistic regression result, highlighted the importance of adiposity measured by Obesity (BMI), Central Obesity (WC) and Visceral Fat as risk factors for hypertension. The mechanisms by which obesity leads tohypertensionis not completely understood. It was thought to be mediated by physical compression by fat around the kidney, followed by activation of the renin-angiotensinaldosterone (RAA) and increased in sympathetic nervous systems activity. These mechanism initially increase renal sodium reabsorption, impair renal-pressure natriuresis, and ultimately raise blood pressure (Hall et al. 2015). Other factors such as lipotoxicity and endothelial and vascular dysfunction may accompany and/or exacerbate increased blood pressure as obesity is sustained. Under physiological conditions, perivascular adipose tissue (PVAT) attenuates agonistinduced vasoconstriction by releasing vasoactive molecules. However, in obese subjects PVAT contributes to endothelial dysfunction, chronic low grade inflammation, vasoconstriction, sodium retention and, consequently, arterial hypertension (Virdis 2016).

Referring to our result where both BMI and $\mathrm{WC}$ are significantly associated with hypertension and only WC was a strong determinant for hypertension, it revokes the old debate whether WC should be measured in addition to or instead of BMI for obesity-related cardio metabolic risk assessment. Data from the INSPIRE ME IAA study provide additional evidence that, rather than replacing BMI as the preferred adiposity index, WC should be assessed in addition to the BMI because the combined use of both

Table 4. Binary logistic regression (backward wald)

\begin{tabular}{lccc}
\hline \multicolumn{1}{c}{ Variable } & B & p & OR $(95 \% \mathrm{CI})$ \\
\hline Constant & -1.77 & 0.467 & \\
Waist circumference & 0.787 & 0.010 & $2.20(1.20-4.01)$ \\
\hline
\end{tabular}

Nagelkerke R Square $=0.46$ anthropometric measures allows for stratification of subjects according to their level of VAT (Nazare et al. 2015). The combination of BMI and $\mathrm{WC}$ is a good surrogate marker of visceral fat accumulation and is useful for monitoring the results of lifestyle changes.

Non-pharmacologic interventions addressing concomitant risk factors, especially those directed at reducing central obesity (eg, caloric and sodium restriction, modest alcohol consumption, regular physical activity) are important for lowering BP and reducing vascular risk in hypertensive women (Geraci \& Geraci 2013). Further, in Indonesian study the risk of obesity in adults can be reduced by not starting smoking at early age and reducing consumption of fatty foods (Sudikno et al. 2018). These life style changes and modification should be offered as early as possible once increase in BMI and/or WC are found to prevent onset of hypertension among women of reproductive age.

Several limitations need to be acknowledged, however, when interpreting the present findings. First, our study was restricted to reproductive-aged women of 20-49 years, which should not be extrapolated to women in other age group. Second, some study data rely on self reported information such as the food recall may be subject to recall and social desirability bias, thus we carefully utilized the food photograph book to guide our data collection procedure a more precise tools such as food models may improve the recall quality. Finally, our study design was cross-sectional, which is limited in establishing causality. In addition, the lack of data regarding the use of hormonal contraception and level of physical activity limit further analysis related to the respondents life style as well as calculation of individual energy need to explain the high average of BMI and WC. Hence, this study is able to offer understanding on the high prevalence of hypertension among rural women of younger cohort as well as its associated factors to design future study. Consequently, our study is also able to provide insight for designing appropriate hypertension screening and prevention method in the Indonesian rural community setting.

\section{CONCLUSION}

The use of the American guideline increases the sensitivity of hypertension screening. The 
prevalence of hypertension screened using the ACC/AHA guidelines in our study population was more than double the prevalence if measured using the $\mathrm{ESC} / \mathrm{ESH}$ guideline (58\% vs $23.8 \%$ ). Socioeconomic characteristics and nutrient intake showed no significant association with hypertension. Body Mass Index (BMI), Visceral Fat (VAT) and Waist Circumference (WC) were significantly associated with hypertension in $\mathrm{Chi}$ Square test. Hence, waist circumference is the strongest determinant for hypertension in our study, where respondents with a WC of above 80 $\mathrm{cm}$ have 2.2 times higer risk to be hypertensive. The use of simple anthropometry measurement of BMI combined with WC together with a routine blood pressure check can be applied for risk screening of hypertension among women of reproductive age in the primary health care setting, including in the integrated community health post during their children visit to improve health care service for women of reproductive age and early management of chronic hypertension. Life style changes and modification should be offered as early as possible once increase in WC and/or BMI in non-pregnant women are found, to prevent earlier onset of hypertension among women of reproductive age. Due to several limitations in the current study, future cross sectional study should consider larger sample size and addresses history of hormonal contraceptive use as well as physical activity. Longitudinal studies will be needed to substantiate evidence on causality of the determinants.

\section{ACKNOWLEDGEMENT}

The authors wish to thank the Neys-van Hoogstraten Foundation, the Netherlands for partially funding the study (IN318).

\section{AUTHOR DISCLOSURES}

The authors have no conflict of interest.

\section{REFERENCES}

Aleixandre A, Miguel M. 2016. Dietary fiber and blood pressure control. Food \& Func 7: 1864-1871. https://doi.org/10.1039/ c5fo00950b.

Angeli F, Reboldi G, Trapasso M, Aita A, Verdecchia P. 2019. Managing hypertension in 2018: Which guideline to follow? Heart Asia 11:1-5. https://doi. org/10.1136/heartasia-2018-011127.

[BPS] Badan Pusat Statistik. 2018. Survey Kesejahteraan Rakyat (Welfare Statistics) 2018. Jakarta (ID): BPS.

Bramham K, Parnell B, Nelson-Piercy C, Seed PT, Poston L, Chappell LC. 2014. Chronic hypertension and pregnancy outcomes: Systematic review and metaanalysis. BMJ 348:g2301. https://doi. org/10.1136/bmj.g2301.

Buendia JR, Bradlee ML, Singer MR, Moore LL. 2015. Diets higher in protein predict lower high blood pressure risk in Framingham offspring study sdults. Am J Hypertens 28(3):372-379. https://doi.org/10.1093/ ajh/hpu157.

Chen HY, Chauhan SP. 2019. Hypertension among women of reproductive age : Impact of 2017 American college of cardiology / American heart association high blood pressure guideline*. IJCHy 1(5):1-6. https://doi.org/10.1016/j. ijchy.2019.100007.

Chopra HK, Ram CVS. 2019. Recent guidelines for hypertension a clarion call for blood pressure control in India. Circ Res 124:984-986. https://doi.org/10.1161/ CIRCRESAHA.119.314789.

Cois A, Ehrlich R. 2014. Analysing the socioeconomic determinants of hypertension in South Africa : A structural equation modelling approach. BMC Public Health 14(414):1-11. https://doi. org/10.1186/1471-2458-14-414.

Diana R, Nurdin NM,AnwarF, Riyadi H, Khomsan A. 2018. Risk factors of hypertension among adult in rural Indonesia. J Gizi Pangan 13(3):111-116. https://doi. org/10.25182/jgp.2018.13.3.111-116.

Elliott P, Stamler J, Dyer AR, Appel L, Dennis B, Kasteloot H, Ueshima H, Okayama A, Chan Q, Garside DB, Zhou B. 2006. Association between protein intake and blood pressure. Arch Intern Med 166(1):79-87. doi:10.1001/archinte.166.1.79.

Fernald LCH, Adler NE. 2008. Blood pressure and socioeconomic status in low-income women in Mexico: A reverse gradient? J Epidemiol Commun H 62(5):1-7. https:// doi.org/10.1136/jech.2007.065219. 
Ferreira HS, Moura FA, Junior CRC, Florencio TMMT, Vieira RC, Assuncao MLD. 2009. Short stature of mothers from an area endemic for undernutrition is associated with obesity, hypertension and stunted children : A population-based study in the semi-arid region of Alagoas, Northeast Brazil. Br J Nutr 101(8):1239-1245. https:// doi.org/10.1017/S0007114508059357.

[GBD] Global Burden of Deases 2016 Risk Factors Collaborators. 2017. Global, regional, and national comparative risk assessment of 84 behavioral, enviromental and occupational, and metabolic risks or clusters of risks, 1990-2016: A systematic analysis for the global burden of disease study 2016. The Lancet 390(10100):13451422.https://doi.org/10.1016/S01406736(17)32366-8.

Geraci TS, Geraci SA. 2013. Considerations in women with hypertension. South Med J 106(7):434-438. https://doi.org/10.1097/ SMJ.0b013e31829bad37.

Goel H, Tayel H, Nadar SK. 2019. Aiming higher in hopes to achieve lower: The European society of cardiology / European society of hypertension versus the American college of cardiology / American heart association guidelines for diagnosis and management of hypertension. J Hum Hypertens 33:635638. https://doi.org/10.1038/s41371-0190227-6.

Hall JE, Carmo JMD, Silva AAD, Wang Z, Hall ME. 2015. Obesity-induced hypertension, interaction of neurohumoral and renal mechanisms. Cir Res 116:991-1006. https://doi.org/10.1161/ CIRCRESAHA.116.305697.

Khanam MA, Lindeboom W, Razzaque A, Niessen L, Milton AH. 2015. Prevalence and determinants of pre-hypertension and hypertension among the adults in rural Bangladesh : Findings from a communitybased study. BMC Public Health 15(203):1-9. https://doi.org/10.1186/ s12889-015-1520-0.

KibriaGMA,BurrowesV,ChoudhuryA,Sharmeen A, Swasey K. 2019. Sex differences in prevalence and associated factors of prehypertension and hypertension among Bangladeshi adults. IJCHy 1:1-6. https:// doi.org/10.1016/j.ijchy.2019.100006.
Kim H, Andrade FCD. 2016. Diagnostic status of hypertension on the adherence to the dietary approaches to stop hypertension (DASH) diet. Prev Med Rep 4:525-531. https://doi. org/10.1016/j.pmedr.2016.09.009.

Li Y, Yang L, Wang L, Zhang M, Huang Z, Deng Q, Zhou M, Chen Z, Wang L. 2017. Burden of hypertension in China: A nationally representative survey of 174,621 adults. Int J Cardiol 227:516-523. https://doi. org/10.1016/j.ijcard.2016.10.110.

Liu H, Yao J, Wang W, Zhang D. 2017. Association between duration of oral contraceptive use and risk of hypertension: A meta-analysis. J Clin Hypertens 19(10):1032-1041. https://doi.org/10.1111/jch.13042.

Mafaza RL, Wirjatmadi B, Adriani M. 2016. Analisis hubungan antara lingkar perut, asupan lemak, dan rasio asupan kalsium magnesium dengan hipertensi. Media Gizi Indonesia 11(2):127-134. http://dx.doi. org/10.20473/mgi.v11i2.127-134.

Mellen PB, Gao SK, Vitolins MZ, Goff Jr DC. 2008. Deteriorating dietary habits among adults with hypertension. Arch Intern Med 168(3):308-314. doi:10.1001/ archinternmed.2007.119.

[MoH RI] Ministry of Health of Republic Indonesia. 2019a. Laporan Nasional Riskesdas 2018. Jakarta (ID): Ministry of Health Republic of Indonesia.

[MoH RI] Ministry of Health of Republic Indonesia. 2019b. Peraturan Menteri Kesehatan Republik Indonesia Nomor 28 Tahun 2019 Tentang Angka Kecukupan Gizi Yang Dianjurkan Untuk Masyarakat Indonesia. Jakarta (ID): Ministry of Health Republic of Indonesia.

Nazare JA, Smith J, Borel AL, Aschner P, Barter P, Gaal LVan, Tan CE, Wittchen HU, Matsuzawa Y, Kadowaki T, Ross R, BrulleWhohlhueter, Almeras N, Haffner SM, Balkau B, Despres JP. 2015. Usefulness of measuring both body mass index and waist circumference for the estimation of visceral adiposity and related cardiometabolic risk profile (from the INSPIRE ME IAA study). Am J Cardiol 115(3):307-15. https://doi. org/10.1016/j.amjcard.2014.10.039.

[NCD-RisC] NCD Risk Factor Collaboration. 2017. Worldwide trends in blood pressure from 1975 to 2015: A pooled analysis 
of 1479 population-based measurement studies with $19 \cdot 1$ million participants. The Lancet 389(10064):37-55. https://doi. org/10.1016/S0140-6736(16)31919-5.

Okorodudu DO, Jumean MF, Montori VM, Romero-Corral A, Somers VK, Erwin PJ, Lopez-Jimenez F. 2010. Diagnostic performance of body mass index to identify obesity as defined by body adiposity: A systematic review and meta-analysis. Int J Obesity 34:791-799. https://doi. org/10.1038/ijo.2010.5.

Ozhan H, Alemdar R, Caglar O, Ordu S, Kaya A, Albayrak S, Turker Y, Bulur S. 2012. Performance of bioelectrical impedance analysis in the diagnosis of metabolic syndrome. J Invest Med 60(3):587-592. http://dx.doi.org/10.2310/ JIM.0b013e318244e2d9.

Pourhoseingholi MA, Vahedi M, Rahimzadeh M. 2013. Sample size calculation in medical studies. Gastroenterol Hepatol Bed Bench 6(1):14-17.

Sichieri R, Siqueira KS, Pereira RA, Ascherio A. 2000. Short stature and hypertension in the city of Rio de Janeiro, Brazil. Public Health Nutrition 3(1):77-82. doi: https:// doi.org/10.1017/S1368980000000094.

Sierra ADL. 2019. New American and European hypertension guidelines, reconciling the differences. Cardiology and Therapy 8(2):157-166. https://doi.org/10.1007/ s40119-019-0144-3.

Stergiou G, Palatini P,Asmar R, SierraADL, Myers M, Shennan A, Wang J, O'brien E, Parati G. 2018. Blood pressure measurement and hypertension diagnosis in the 2017 US guidelines, first things first. Hypertension 71:963-965. https://doi.org/10.1161/ HYPERTENSIONAHA.118.10853.

Streppel MT, Arends LR, Veer PV, Grobbee DE, Geleijnse JM. 2005. Dietary fiber and blood pressure. Arch Intern Med 165(2): 150-156. doi:10.1001/archinte.165.2.150.

Sudikno, Syarief H, Dwiriani CM, Riyadi H, Pradono J. 2018. Obesity risk factors among 25-65 years old adults in Bogor City, Indonesia: A prospective cohort study. J. Gizi Pangan 13(12):55-62. https:// doi.org/10.25182/jgp.2018.13.2.55-62.

Takahashi H, Yoshika M, Komiyama Y, Nishimura M. 2011. The central mechanism underlying hypertension: A review of the roles of sodium ions, epithelial sodium channels, the renin - angiotensin aldosterone system, oxidative stress and endogenous digitalis in the brain. Hypertension Research 34:1147-1160. https://doi.org/10.1038/hr.2011.105.

Tyagi R, Dhall M, Kapoor S. 2015. Biosocial predictors of hypertension among premenopausal and postmenopausal women. SAGE Open January-March:1-12. https://doi. org/10.1177/2158244015574227.

Virdis A. 2016. Endothelial dysfunction in obesity : Role of inflammation. High Blood Pressure \& Cardiovascular Prevention 23(2):83-85. https://doi.org/10.1007/ s40292-016-0133-8.

Wang L, Manson JE, Forman JP, Gaziano JM, Buring JE, Sesso HD. 2010. Dietary fatty acids and the risk of hypertension in middleAged and older women. Hypertension 56(4):598-604. https://doi.org/10.1161/ HYPERTENSIONAHA.110.154187.

Wenger NK, Do AA, Merz CNB, Cooper-DeHoff RMC, Ferdinand KC, Fleg JL, Gulati M. Isiadinso I, Itchhaporia D, Light-Mcgroary $\mathrm{K}$, Lindley KJ, Mieres JH, Rosser ML, Saade GR, Walsh MN, Pepine CJ. 2018. Hypertension across a woman's life cycle. J Am Coll Cardiol 71(16):1797-1813. https://doi.org/10.1016/j.jacc.2018.02.033.

Williams B, Mancia G, Spiering W, Rosei EA, Azizi M, Burnier M, Clement DL, Coca A, De Simone G, Dominiczak A, et al. 2018. 2018 ESC / ESH Guidelines for the management of arterial hypertension. The task force for the management of arterial hypertension of the European society of cardiology (ESC) and the European society of hypertension (ESH). European Heart Journal 39(33):3021-3104. https:// doi.org/10.1093/eurheartj/ehy339.

[WHO] World Health Organization. Expert Consultation. 2004. Public health. Appropriate body-mass index for Asian populations and its implications for policy and intervention strategies. The Lancet, 363:157-163.

[WHO] World Health Organization. Expert Consultation. 2008. Waist Circumference and Waist-Hip Ratio, Report of a WHO Expert Consultation. Geneva $(\mathrm{CH})$ :WHO. 